University of Puget Sound

Sound Ideas

All Faculty Scholarship

Faculty Scholarship

$6-1-2007$

\title{
Mutiny Echoes: India, Britons, And Charles Dickens's A 'tale Of Two Cities'
}

Priti Joshi

University of Puget Sound, pjoshi@pugetsound.edu

Follow this and additional works at: http://soundideas.pugetsound.edu/faculty_pubs

\section{Citation}

Joshi, Priti. 2007. "Mutiny echoes: India, Britons, and Charles Dickens's A 'Tale of Two Cities'." Nineteenth-century Literature 62(1): 48-87.

This Article is brought to you for free and open access by the Faculty Scholarship at Sound Ideas. It has been accepted for inclusion in All Faculty Scholarship by an authorized administrator of Sound Ideas. For more information, please contact soundideas@pugetsound.edu. 
Mutiny Echoes: India, Britons, and Charles Dickens's A Tale of Two Cities Author(s): PRITI JOSHI

Source: Nineteenth-Century Literature, Vol. 62, No. 1 (June 2007), pp. 48-87

Published by: University of California Press

Stable URL: http://www.jstor.org/stable/10.1525/ncl.2007.62.1.48

Accessed: $21 / 10 / 2014$ 18:46

Your use of the JSTOR archive indicates your acceptance of the Terms \& Conditions of Use, available at http://www.jstor.org/page/info/about/policies/terms.jsp

JSTOR is a not-for-profit service that helps scholars, researchers, and students discover, use, and build upon a wide range of content in a trusted digital archive. We use information technology and tools to increase productivity and facilitate new forms of scholarship. For more information about JSTOR, please contact support@ jstor.org. 


\title{
Mutiny Echoes: India, Britons, and Charles Dickens's A Tale of Two Cities
}

\author{
PRITI JOSHI
}

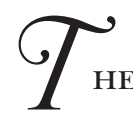

HE nineteenth-century English novel frequently banished troublesome characters or thorny social issues to the colonies or other peripheries. The classic example is Elizabeth Gaskell's Mary Barton (1848), whose protagonists escape to Canada-an escape that, as Raymond Williams has pointed out, hardly inspires confidence in the solution of brotherhood that the narrator promulgates. ${ }^{1}$ The colonies also served to regulate "second sons"-Rochesters and Magwitches-whose wayward behavior was spent and disciplined abroad. In such examples, empire, only marginally visible, serves as the proverbial escape hatch. My focus in this essay, however, is on a novel that does not engage with empire, even in its peripheries, a novel that instead appears to suppress colonial questions altogether. What makes this elision puzzling and noteworthy is that colonial events were at the forefront of the novel's conception and con-

Nineteenth-Century Literature, Vol. 62, No. 1, pp. 48-87. ISSN: o891-9356, online ISSN: $1067-835^{2}$. (C) 2007 by The Regents of the University of California. All rights reserved. Please direct all requests for permission to photocopy or reproduce article content through the University of California Press's Rights and Permissions website, at http:/ / www.ucpress.edu/journals/rights.htm.

${ }^{1}$ See Williams, Culture and Society, I780-1950 (New York: Columbia Univ. Press, $195^{8), \text { p. }} 9^{1}$. 
cerns. I refer to Charles Dickens's A Tale of Two Cities (1859), a novel whose first numbers appeared less than two years after the start of what is generally know as the Indian "Mutiny." 2

The events of 1857-59 on the Indian subcontinent surprised and shook Britons. In the face of the seemingly maniacal uprising, Britons, almost to a person, reacted explosively. In an October 1857 letter, Dickens wrote: "I wish I were Commander in Chief in India. . . . I should do my utmost to exterminate the Race upon whom the stain of the late cruelties rested ... to blot it out of mankind and raze it off the face of the Earth." ${ }^{3}$ Most modern readers wince at this extremism (Peter Ackroyd, a Dickens biographer, has dryly commented: "It is not often that a great novelist recommends genocide"), ${ }^{4}$ and remarks such as

\footnotetext{
2 Although today most scholars of South Asia eschew the word "Mutiny" to describe the events of 1857-59, the term persists as the popular shorthand for the events that began on the subcontinent that summer, as in the title of the most recent popular history of events, Saul David's The Indian Mutiny, I 857 (Harmondsworth: Penguin, 2002). Francis G. Hutchins notes that the term "mutiny" was used because the British "wished to emphasize its treasonous nature" and to suggest that the uprising "was confined to the Indian troops of the British Army" (Hutchins, The Illusion of Permanence: British Imperialism in India [Princeton: Princeton Univ. Press, 1967], p. 79, n. 2). As any number of historians have demonstrated, however, while the events began as a mutiny on military barracks, the rebels rapidly gathered large numbers of civilians into their embrace, peasants as well as elites, whose grievances were distinct from those of the soldiers (see Rudrangshu Mukherjee, "'Satan Let Loose Upon Earth': The Kanpur Massacres in India in the Revolt of 1857 ," Past and Present, no. 128 [1990], 99). Yet to call the uprising a "War of Independence," as some Indian nationalist historians have suggested, is equally inaccurate: the insurgency had little coherence, unity, staying power, or "national" character (see Ainslie T. Embree, I857 in India: Mutiny or War of Independence? [Boston: D. C. Heath and Co., 1963]). In his compact history of India, Ranbir Vohra calls the event "The Great Rebellion of 1857 " and rejects the argument that it was a war of independence. His conclusion is cogent and balanced: "if one reflects on the fact that vast numbers of non-British civilian and military elements, of their own volition, joined the rebels, the rebellion-however limited in extent-did possess a pseudo-national flavor. It was the first time in the history of India that so many disparate elements, from many diverse regions, although guided by conflicting aims and lacking a unified organization or program, made a foreign power the common target for attack" (Ranbir Vohra, The Making of India: A Historical Survey, 2d ed. [Armonk, N.Y., and London: M. E. Sharpe, 1997, 2001], p. 72). In this essay I use the terms "Rebellion," "Uprising," or simply "1 857 " to refer to the events, and "Mutiny" only when speaking of nineteenth-century British perceptions of it.

${ }^{3}$ Charles Dickens, letter to Angela Burdett Coutts, 4 October 1857 , in The Letters of Charles Dickens, ed. Madeline House, Graham Storey, and Kathleen Tillotson, et al., 12 vols. (Oxford: Clarendon Press, 1965-2002), VIII, 459 (hereafter referred to as Letters).

${ }^{4}$ Peter Ackroyd, Dickens (London: Sinclair-Stevenson, 1990), p. 799.
} 
this one have led to debates about the existence, extent, and depth of Dickens's "racism." ${ }^{5}$ What is lost in this debate, however, is the fact that Dickens was not alone in reacting strongly to the news from India: Thomas Babington Macaulay, for example, wrote that accounts of Indians being blown from the mouth of cannon were "read with delight by people who three weeks ago were against all capital punishment." 6 The historian Graham Dawson, in his analysis of a number of dailies, has found that periodicals such as the Times, Morning Post, and Lloyd's Weekly called for "vengeance" and "extermination." Thus, while Dickens had a personal investment in the matter (his sixteen-year-old son, Walter, had joined the East India Company and set sail for Calcutta on 20 July 1857 , only a week

\footnotetext{
${ }^{5}$ Patrick Brantlinger, for instance, has little tolerance for Dickens's "genocidal attitudes" (see Brantlinger, Rule of Darkness: British Literature and Imperialism, I830-I9I4 [Ithaca: Cornell Univ. Press, 1988], p. 126). The editors of The Letters of Charles Dickens are more generous, commenting that Dickens's "imaginary threats of revenge were less horrific than those expressed by many British commanders in the field as well as by sectors of the press in both India and England" (Letters, VIII, 459-6o, n. 8). More recently, Grace Moore has entered the fray, arguing that Dickens's "fury at the sepoy rebels" was merely an expression of "his long-held anger at domestic maladministration and nepotism." She writes: "The violent upheaval thousands of miles away provided Dickens with a target onto which he could legitimately discharge his fury. . . . it was much easier to hit out at the sepoy rebels than the British government. . . The horrors of the Bibighar at Cawnpore ... allow[ed] him to call for retribution in a way that he could never do when attacking organizations like the British government" (Grace Moore, Dickens and Empire: Discourses of Class, Race and Colonialism in the Works of Charles Dickens [Burlington, Vt.: Ashgate, 2004], p. 126). This explanation-that Dickens displaced his frustration with domestic politics onto Indians-exonerates him too readily. Even if we accept Moore's substitution, it only highlights the problem: that anger at British policies could be "legitimately" displaced and discharged onto a racial Other indicates a racial discourse in which the Other becomes a ready target, a convenient repository to explain away locally produced social ills. As will be clear from what follows, I believe that the debate itself-is Dickens a racist, or are we imposing our sensibilities on him?-is too narrowly construed.

${ }^{6}$ Thomas Babington Macaulay, as quoted in Hutchins, The Illusion of Permanence, p. 85. The original source is G. Otto Trevelyan, The Life and Letters of Lord Macaulay, 2 vols. (New York: Harper and Brothers, 1875), II, 366.

${ }^{7}$ Graham Dawson, Soldier Heroes: British Adventure, Empire and the Imagining of Masculinities (London and New York: Routledge, 1994), p. 94. The point is also made by James Bryne, who cites the Times's editorial position on 6 August 1857 calling for "a terrible example" and the Morning Post's call on 5 September 1857 for "exterminati[on]" (see Byrne, "British Opinion and the Indian Revolt," in Rebellion I 857: A Symposium, ed. P. C. Joshi [New Delhi: People's Publishing House, 1957], pp. 297-98).
} 
before reports of the Rebellion arrived in London), his sentiments, as so often, echoed those of the majority of his compatriots as well as guided them: his 1857 Christmas story, about innocent Britons encountering "hostile attack" in a "strange wild place," 8 mirrored the general understanding in Britain of the "Mutiny." And neither was his interest in India fleeting: that year Dickens committed Household Words to John Lang's thirteen-part "Wanderings in India," published between November 1857 and February $185^{8}$.

Yet when Dickens began his next novel in February 1859, he turned to a more distant upheaval, the French Revolution of 1789. Why did Dickens choose to write about the French Revolution when the crisis uppermost in his and most Britons' minds was the Indian "Mutiny"? More important, what, if any, relationship exists between the events in India and Dickens's account of the French Revolution? Where, if at all, is the Indian "Mutiny" in A Tale of Two Cities? Ghosts, spirits, echoes, and specters abound in this novel, a tale about the repressed pastpersonal, social, political, historical-returning to haunt the present. In the spirit of the novel's central themes, then, we may reasonably ask: what might $A$ Tale be haunted by? What might it echo? What spirits help to conjure the novel, and what spirits might it suppress?

Dickens's choice of subject matter and timing has long intrigued critics, although few have asked the question in terms of India. Andrew Sanders provides a typical explanation: "The subject of the French Revolution loomed large in the consciousness of nineteenth-century England . . . because its social violence and blood-letting seemed to undermine the notion of steady and happy progress into the future." ${ }^{9}$ This explanation draws attention to Dickens's growing skepticism and turn to somber subjects in the 185 os. This was, after all, the decade that began with his critique of the Crystal Palace, that paean to British progress, and continued with Bleak House (1852-53) and Little Dorrit $(1855-57)$, his denunciations of bureaucratic

\footnotetext{
${ }^{8}$ Charles Dickens, letter to Henry Morley, 18 October 1857 , in Letters, VIII, 469 .

${ }^{9}$ Andrew Sanders, introduction to Charles Dickens, A Tale of Two Cities, ed. Sanders (New York: Oxford Univ. Press, 1988), p. xix.
} 
"How Not To Do It"-ism, prison, and self-imprisonment. From this perspective, A Tale of Two Cities develops themes that had been preoccupying Dickens for some time, and the French Revolution was merely the backdrop against which he investigated those themes. Other critics have explained Dickens's turn to 1789 by looking at the state of Anglo-French relations. Stanford University's "Discovering Dickens" web site most explicitly reflects this position - and its limitations. The editors explain that after Louis Napoleon declared himself emperor in $185^{2}$,

Though relations were essentially peaceful between England and the Second Empire, the British tended to perceive a second Emperor Napoleon as a possible threat, and the French were not endeared to the English by events of 1858: An assassination attempt on Louis Napoleon and his Empress disclosed a plot organized by a group of French people living in England. This plot, perpetrated with grenades of Birmingham manufacture, increased French-English tensions in the year before A Tale of Two Cities was published; however, it did not have serious consequences for international relations. ${ }^{10}$

The emphasis on a remote plot that even the editors admit had few "serious consequences" to the exclusion of events of far greater political magnitude and resonance appears not only too literal, but also narrowly Eurocentric.

Mutiny or rebellion in one form or another, however, appears early and often in A Tale of Two Cities: in the opening pages the "mutinous" horses on the Dover mail refuse to carry the passengers uphill. ${ }^{11}$ But animals are not the only ones to resist: from the humorous to the increasingly treacherous, the novel gives us Jerry Cruncher, the grave-robber, who rebels against the respectability of Tellson's; Roger Cly, Darnay's servant, who turns state's evidence against his master after rummaging through his drawers; Barsad, who double-crosses his nation by serving first Britain and then France as spy; and

10 "A Tale of Two Cities: Two Historical Moments," in "Discovering Dickens: A Community Reading Project," at <http://dickens.stanford.edu/archive/tale/historical _context.html>.

${ }^{11}$ Charles Dickens, A Tale of Two Cities, ed. Sanders, p. 5. Subsequent references to the novel are from this edition and are included in the text. 
Defarge, who repeatedly turns against his former master, most traitorously when he brings Madame to knit Lucie into her design (Tale of Two Cities, p. 326). Nowhere is mutiny more concentrated, however, than in Madame Defarge, whose steely determination violates - mutinies against - the norms of gender. She not only initiates the Terror by slicing off the Bastille governor's head with her knife (p. 268), but also stonily rebuffs Lucie's appeal to her sisterly heart (p. 329) and Defarge's pleas to save Lucie and her child. "Tell the Wind and the Fire where to stop; not me!" (p. 421 ), cries Madame in the terrifying voice of a vengeful subject who will not be halted.

What might we infer from such representations of betrayal, rebellion, and mutiny? Is the Indian "Mutiny" a subtext of A Tale of Two Cities? Does the novel compare the French Revolution and the Indian Uprising? Among only a handful of critics who have examined the relationship between the novel and 1857 , Patrick Brantlinger argues that although there are "coincidences" in Dickens's novel that "suggest India," "no obvious parallels are drawn in the novel between the events of the French Revolution and those of the Mutiny," largely because Dickens "did not view the Mutiny as the result of oppressive government" (Rule of Darkness, p. 208). Grace Moore, in contrast, is persuaded that by 1859 Dickens was "more responsive to the Indians' grievances," and suggests: "The Parisian mob does not simply represent the sepoys in India, but also the working classes of Britain. . . . Dickens's fusion of the French Revolution with British working-class unrest and the sepoy insurrection, is itself paradigmatic of the developments in his thinking by 1859" (Dickens and Empire, pp. 130, 129). Brantlinger and Moore, albeit diametrically opposite in their conclusions, begin as I do at the start of this essay: searching for parallels or a possible family resemblance between Dickens's account of the French Revolution and India. William Oddie, by contrast, in his 1972 essay "Dickens and the Indian Mutiny," places the Uprising in a larger context, examining Britons' reactions to it in a range of works (letters, diaries, cartoons, short stories). In a brief discussion of Dickens's novel, Oddie concludes: "the Indian Mutiny cannot . . . be seen as a full explanation of the intensity of Dickens's depiction of the fall of the 
Bastille. ... Nevertheless, I am sure that, behind the fevered intensity of Dickens's evocations of French atrocities must lie also his feelings about the massacre of English victims in India." ${ }^{12}$ In Oddie's careful rendering, the Indian "Mutiny," rather than being represented allegorically or analogically in A Tale of Two Cities, was a catalyst, a fuel, or, to use an entirely different metaphor, a lens through which Dickens viewed the French Revolution and that shaped his understanding of it.

My approach here is closer in spirit to Oddie's, although my conclusions differ. I extend the range of works examined, discussing Dickens's pre- "Mutiny" short fiction and journalism as well. My aim is to broaden the scope in order to develop an account of Dickens's thinking about identity and Otherness. While his novels of the 185 os-Bleak House, Hard Times (1854), Little Dorrit-are set in Britain and rage at bureaucracy and its numbing effects on individuals, Dickens's short stories are consistently located in colonial or offshore settings where his characters, in the face of adversity, rise to heroism. Together with his journalistic essays in Household Words, the stories attest to a desire for a simple, uncomplicated world, one in which recognizing and embracing his_-and the emphasis was decidedly on a masculine figure-identity as a Briton leads the protagonist to act nobly and valiantly. These writings indicate that the flip side of Dickens's critique of British institutions and bureaucracy was both an anxiety about the enervating influence of prosperity and domesticity and, as antidote, the craving for a landscape in which the hero is unfettered and free to express himself as British. In the nineteenth century, such a landscape was necessarily overseas and inevitably imperial. It was also a landscape that was sparsely populated with women, or rather, was populated with the sort of woman who enabled the emergence of this heroic masculinity. The "Mutiny" occurred against this cultural backdrop-of the appetite for adventure, of the recoil from bureaucracy and domesticity, of the consolidation of national identity. In Britain, the events in India were scripted as a romance of heroic masculinity and imperiled womanhood, a national drama - of British valor versus Indian cowardice- that

${ }^{12}$ William Oddie, "Dickens and the Indian Mutiny," The Dickensian, 68 (1972), 15 . 
was conceived in gendered terms. In this formulation, 1857 provided the literal landscape on which heroism, fortitude, and masculinity were realized. A Tale of Two Cities was written in the shadow of the "Mutiny"; illuminating that shadow and reading the novel against it, I demonstrate that while the novel's setting is late-eighteenth-century France, one of its central concerns is a mid-nineteenth-century English one-the consolidation of British national identity, an issue that received a considerable boost in the wake of the Indian "Mutiny."

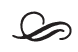

The outline of the events of 1857 are well known: the rifle cartridges, rumored to be greased with cow or pig fat; the overzealous court-martial of eighty-five sepoys at Meerut; their comrades mutinying on 10 May 1857 , killing officers and burning cantonment buildings; the spread outward from barrack to town; and the further dissemination of the uprising to a number of towns across the North-West Provinces, each time repeating the same pattern: sepoys mutiny, merge into the civilian population, approach a local leader ousted by the British, and give him (in one case her) little choice but to head the insurgency. Scores of British officers and civilians were killed, while those who survived retreated to hastily constructed entrenchments where they were trapped, often for months, until reinforcements arrived. Colonel James Neill led the reinforcement from Calcutta, and, as his forces made their way through the plains, they initiated a reign of retribution, indiscriminately burning villages and hanging people regardless of their role in the uprising (some had aided Britons), and inflaming the rapidly spreading rebellion.

The uprising came as a surprise to the British. In its early days every commander insisted that his sepoys would remain loyal; as one officer put it: "They're all niggers alike. . . . But I can trust my fellows." 13 The faith in "my fellows" was well

${ }_{13}$ As quoted in Christopher Hibbert, The Great Mutiny: India 1857 (New York: Viking Press, 1978), p. 127. The original source is William Howard Russell, My Diary in India, in the Year I $858-9$ (1860). 
founded in many cases, but not all. In Britain early reactions were relatively restrained. On 27 July 1857 , Benjamin Disraeli warned the Commons that the uprising was not just a military mutiny but a national revolt and evidence of "general discontent." 14 The speech earned him a full-page Punch denunciation, "The Asiatic Mystery," where he is Orientalized (in posture, features, setting, and task), demoted to a sepoy, and identified as a traitor who, in league with the King of Oudh, produced the "pickle" (see Figure 1). Despite its attack on Disraeli for intimating that the uprising may have legitimate causes, Punch ran a spread the following week itself targeting the East India Company. In the "Execution of 'John Company," a cannon blows open the Company, exposing a clown figurehead and Avarice, Blundering, Nepotism, Misgovernment, and Supineness (see Figure 2). The charge was a familiar one-in the previous decade, Victorian newspapers and periodicals including Household Words ran articles exposing the Company's mismanagement, ineptitude, and harsh taxation policies. ${ }^{15}$ The harassed but hardly surprised looking babu (Indian clerk) silently witnessing the scene in the "John Company" cartoon suggests that Punch believed it spoke for Indians' grievances as well as identified with them against the Company. Disraeli's comment and Punch's indictment indicate that in the early days reactions to events in India were not polarized and jingoistic, as they were to become shortly.

As detailed reports of British soldiers and civilians in poorly equipped garrisons started to arrive in London (in 1857 , aside from brief telegraphs, reports from India to Britain

\footnotetext{
${ }^{14}$ Benjamin Disraeli, as quoted in Thomas R. Metcalf, The Aftermath of Revolt: India, I857-I87o (Princeton: Princeton Univ. Press, 1964), p. 73 .

15 Grace Moore concludes: "Prior to the uprising, however, Household Words had been the dominant player in exposing the East India Company's nepotism through investigative pieces like John Capper's 'The Great Indian Bean-Stalk' and 'A Pull at the Pagoda Tree.'. . . One would imagine from the type of articles that appeared in Household Words in the 185 os, that the Indian Mutiny would have been no surprise to Dickens" (Dickens and Empire, p. 108). Given the attacks on nepotism, it is discomfiting to learn that Dickens did not hesitate to use his connections to secure Walter's appointment as cadet to the Company's army: Angela Burdett Coutts, a significant shareholder of the East India Company, used her right of patronage to obtain the appointment (see Dick Kooiman, "The Short Career of Walter Dickens in India," The Dickensian, 98 [2002], 16).
} 


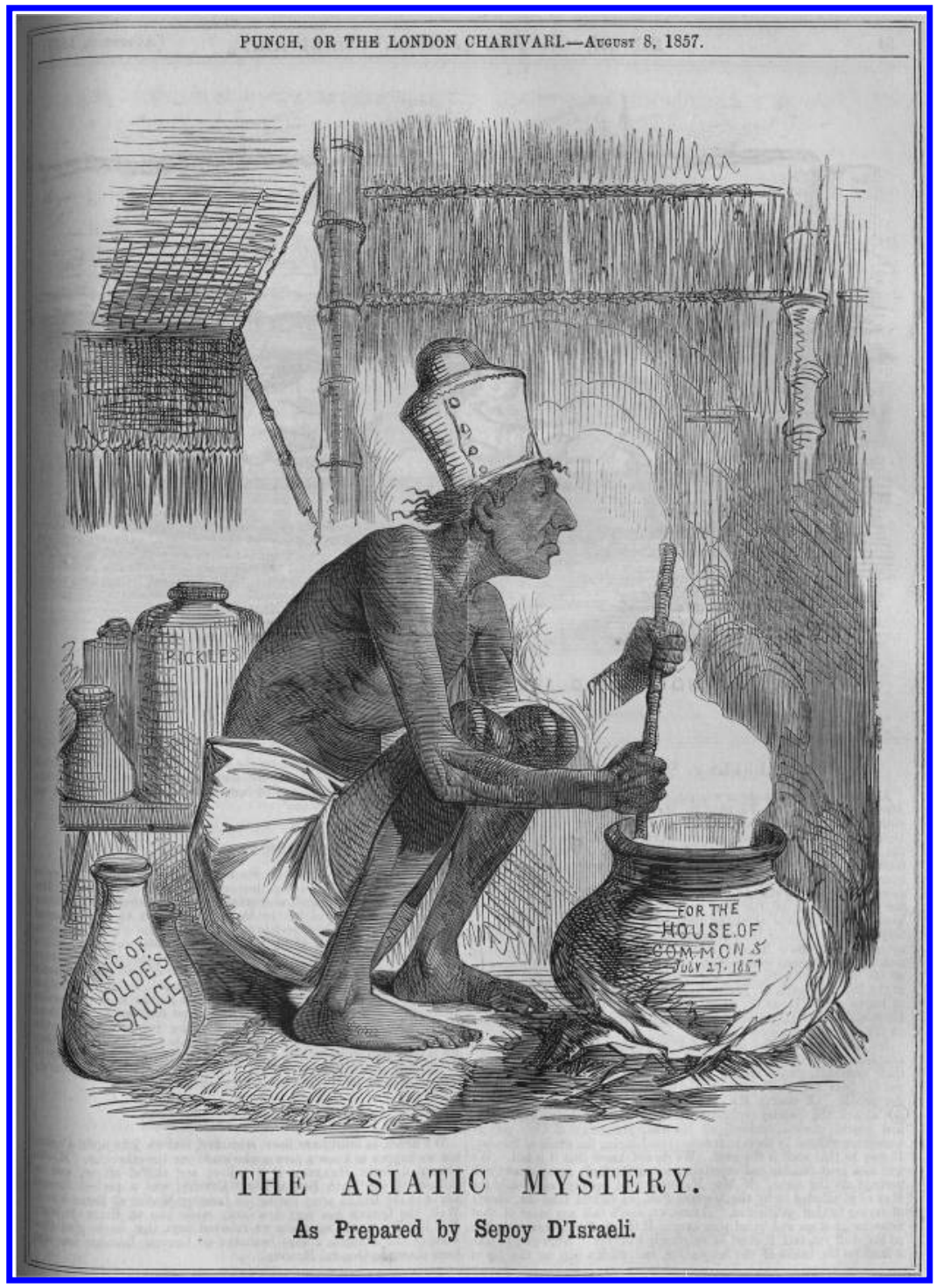

Figure 1. "The Asiatic Mystery. As Prepared by Sepoy D'Israeli," Punch, 33 (1857), 55 . 


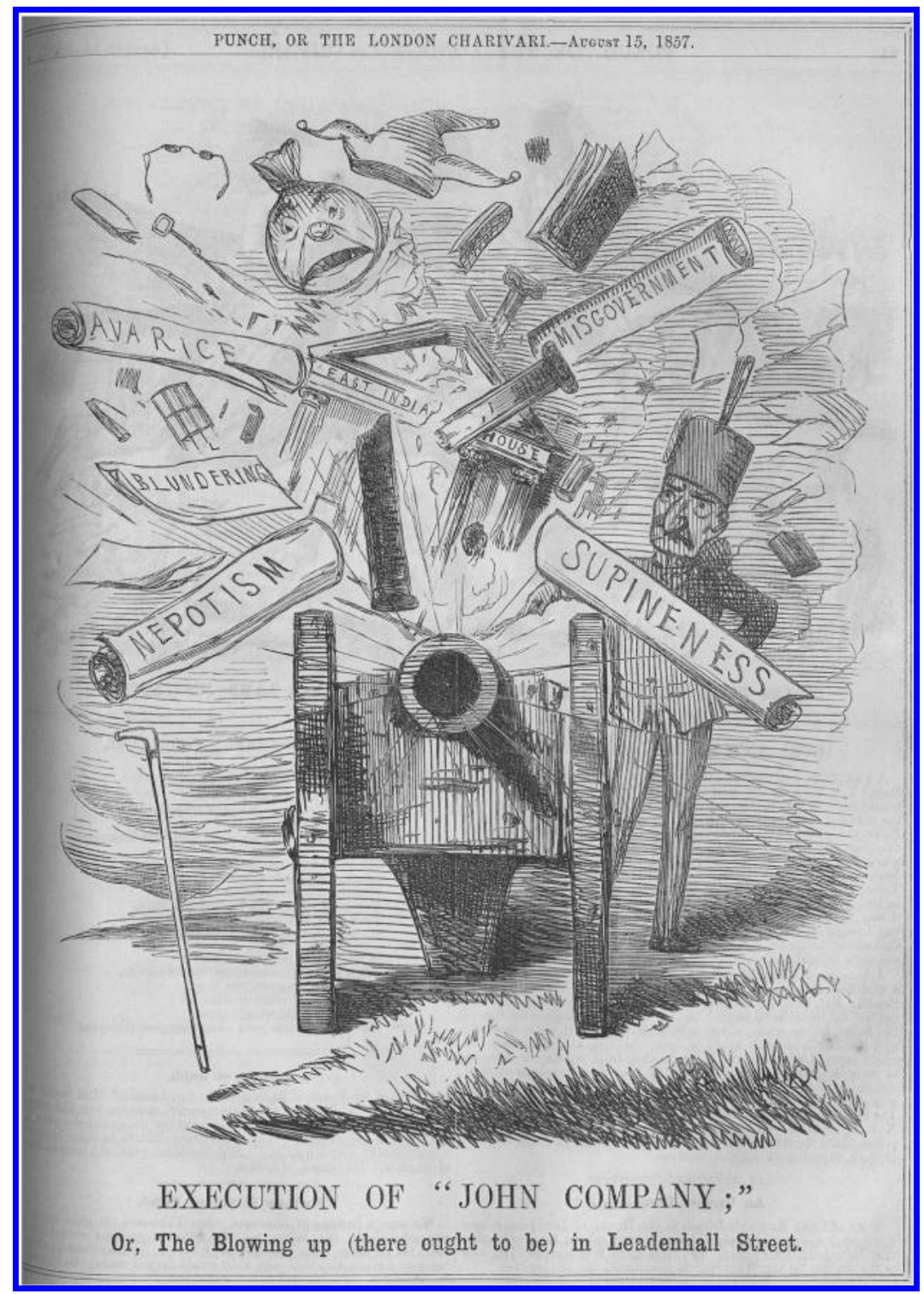

Figure 2. "Execution of 'John Company;' Or, The Blowing up (there ought to be) in Leadenhall Street," Punch, 33 (1857), 65 . 
took approximately thirty days to arrive),${ }^{16}$ the tenor of the response altered, becoming dramatically racialized and jingoistic. For Britons the key events of the "Mutiny" were the sieges of Delhi, Lucknow, and Kanpur (or Cawnpore, as it was called), and of these none was seared more intensely into the national imagination as Kanpur. There, after almost a month under siege, the commander General Wheeler negotiated safe passage for the $45^{\circ}$ British men and women trapped in the garrison. As the British stepped into the boats that were to carry them to safety, the rebels opened fire and killed most of the men. The surviving women and children were escorted to the infamous Bibighar - no doubt this was somebody's idea of a grim joke, as the house was built by an eighteenth-century British officer for his Indian mistress. ${ }^{17}$ The Bibighar was a criminally small space, utterly inappropriate and ill equipped for the approximately one hundred and fifty inhabitants, many of whom succumbed to disease and death. Two weeks later, as British forces approached Kanpur, the women and children who had managed to survive were brutally murdered and their bodies thrown into a well.

No episode of the rebellion aroused more horror than the "Well at Cawnpore." For Britons it captured the "Indian character" of cowardice and treachery and legitimized a ferocious military response. John William Kaye, the preeminent nineteenth-century historian of the Rebellion, wrote that the British response was "to punish and to awe." 18 Colonel Neill was particularly sadistic, requiring each man, before execution, to lick the blood off of one square foot of the floor of the Bibighar. ${ }^{19}$ The building became a shrine that British soldiers visited on their way to battle. According to Private Henry Metcalfe, the Highlanders, upon seeing the scene at Cawnpore, "took a Highland oath that for every one of our poor creatures

${ }^{16}$ See Dawson, Soldier Heroes, pp. 84-85.

${ }^{17}$ See Andrew Ward, Our Bones Are Scattered: The Cawnpore Massacres and the Indian Mutiny of 1857 (New York: Henry Holt and Co., 1996), p. 372.

${ }^{18}$ John William Kaye, as quoted in Mukherjee, "Satan Let Loose," p. 112. The original source is Kaye's A History of the Sepoy War in India, I857-1858, 5 th ed. (1888), 3 vols. (London: Longman, Green, and Co., 1896), II, 269.

${ }^{19}$ See Hibbert, The Great Mutiny, p. 210. 
who were thus slain, 100 of the enemy should bite the dust, and I need not add that they kept their vow." ${ }^{20}$ Hibbert quotes Garnet Wolseley, a captain, who "made the vow that 'most soldiers made there - of vengeance and of having blood for blood, not drop for drop, but barrels and barrels of the filth which flows in these niggers' veins for every drop of blood which marked the floors and walls of that fearful house." "21 The cry "Remember the ladies, Remember the babies" was said to be on every man's lips as he went into battle. ${ }^{22}$ Kanpur made Britons out of many for whom India had been a remote, exotic place, and it serves as textbook case of Benedict Anderson's argument about the role of print media in producing - or fortifying — that collective act of imagination called the nation. ${ }^{23}$

The Bibighar massacre turned the tide of public opinion and carried Britons on a wave of rage and patriotism that prevented reflection. The horror of the women's grisly fate merged with anxieties about cannibalism and rape to produce lurid accounts of atrocities committed by Indians. A report in the Times on 17 September 1857 , for instance, claimed: "Children have been compelled to eat the quivering flesh of their murdered parents, after which they were literally torn asunder by the laughing fiends who surrounded them." ${ }^{24}$ Second- or thirdhand accounts of British women "dishonoured" by Indians circulated freely in newspapers and magazines. On 25 August 1857 the Times printed a letter dated 4 July from a clergyman writing from Bangalore, who claimed:

They took 48 females, most of them girls of from 10 to 14 , many delicately nurtured ladies, - violated them, and kept them for the base purposes of the heads of the insurrection for a whole

\footnotetext{
${ }^{20}$ Henry Metcalfe, as quoted in Hibbert, The Great Mutiny, p. 212. The original source is Metcalfe's The Chronicle of Private Henry Metcalfe, H.M. 32 nd Regiment of Foot, Together with Lieutenant John Edmonstone's Letter to His Mother of 4 th January I 858 , ed. Francis Tuker (London: Cassell and Co., 1953), p. 68.

${ }^{21}$ See Hibbert, The Great Mutiny, p. 21 , quoting Garnet Wolseley from the Wolseley Papers, Wolseley Library, Hove.

${ }^{22}$ See Dawson, Soldier Heroes, p. 97. Dawson is quoting from the 1857 pamphlet Who and What is Havelock?

${ }^{23}$ See Benedict Anderson, Imagined Communities: Reflections on the Origin and Spread of Nationalism, rev. ed. (London and New York: Verso, 1991).

24 "The Mutinies in India," London Times, 17 September 1857 , p. 9.
} 
week. At the end of that time they made them strip themselves, and gave them up to the lowest of the people to abuse in broad daylight in the streets of Delhi. ${ }^{25}$

Although British investigators as early as 1858 concluded that the allegations of rape, cannibalism, and mutilation were fabrications, that did not halt the circulation of such tales or the status of rape as the central trope of the "Mutiny." 26

Jenny Sharpe has written of the British military response in India: "the knightly virtues of honor, a veneration of women, and protection of the weak were invoked" so that the response of the army could be made to look like "a momentary fit of rage rather than the exercise of a power licensed by martial law" (Allegories of Empire, pp. 76-77). In Britain as well, the icon of innocent Englishwomen was used to camouflage or legitimize revenge. On 10 October, roughly a month after reports of the Bibighar massacre arrived in Britain, a Punch cartoon titled "O God of Battles! Steel My Soldiers' Hearts!" transformed the vengeance of responses such as the soldiers's and Dickens's extermination remark into a stirring and uplifting image (see Figure 3). A girlish and anguished Queen Victoria is surrounded by weeping and praying women and children. Embraced by the monarch and in the orbit of that irreproachable English icon, William Shakespeare, the anonymous women and ragged children are drawn into the polity to become Britons. Their innocence provides cover for the violent tag line that endorses revenge. Thus were femininity and sentiment deployed to mask aggression, or to whitewash aggression as innocent purity. It is ironic that the cartoon's depiction of Victoria beseeching masculine aid unwittingly exposes the contradictory position that such an iconography placed Victorian women in: powerful as generative icons but passive and dependent on male agency. The cartoon is one of the earliest indications that the story of

25 [Anon.], 4 July 1857 letter, London Times, 25 August 1857, p. 6. Jenny Sharpe notes that this letter was reprinted in several newspapers (see Sharpe, Allegories of Empire: The Figure of Woman in the Colonial Text [Minneapolis: Univ. of Minnesota Press, 1993], p. 66).

${ }^{26}$ See Mukherjee, "Satan Let Loose," pp. 115-16; and Sharpe, Allegories of Empire, pp. $64-65$. 


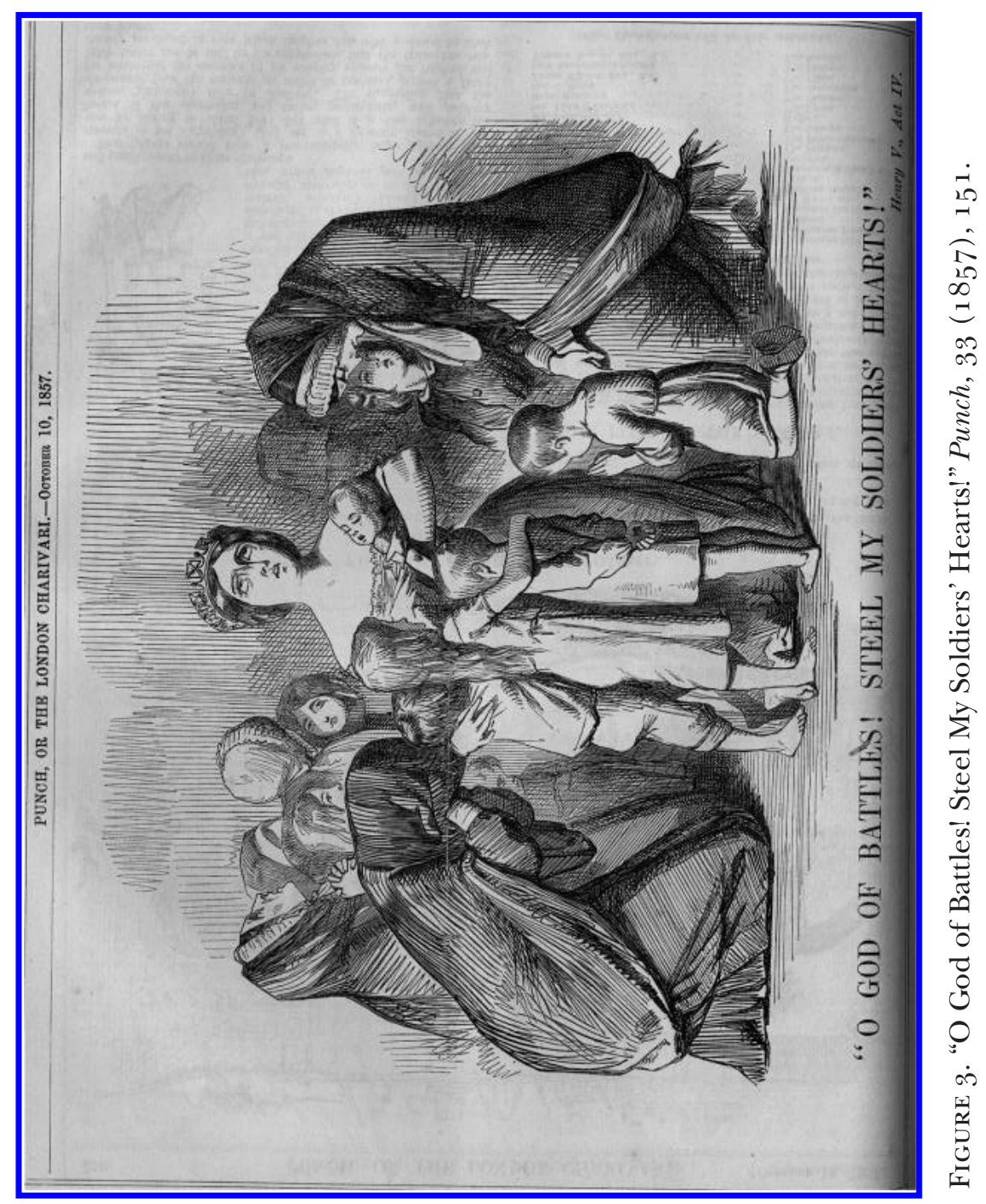


1857 would be reduced to a narrative of the violation of English femininity, a narrative anchored in and dependent on what were seen as proper gender roles.

Corresponding to the icon of the vulnerable British woman in need of rescue was that of the heroic and chivalric British man. We have already seen this man announce himself in the Highland oath; in Britain he made a dramatic appearance in a pair of Punch cartoons. On 22 August 1857 the magazine ran the first of only three double-page spreads of the year, John Tenniel's “The British Lion's Vengeance on the Bengal Tiger" (see Figure 4). The image displays a dark tiger poised over a supine and bare-shouldered woman (hinting at rape) and child. The tiger cowers at the advance of a powerful lion who fills three-quarters of the image. The divided frame and minimalist brush strokes communicate a simple story-of imperiled womanhood and valiant masculinity rushing to the rescue. The following week Punch carried a second two-page spread, also by Tenniel. "Willing Hands for India" too is neatly divided: in the left frame are a straggling band of simpleton, bow-legged rurals who are transformed into tall, straightbacked, handsomely dressed, hatted and booted, muscular men as they move into the right frame, from Britain to Britons (see Figure 5). Their transformation is effected as they literally "step up" to "India," where they come into their national identity and masculinity. It is telling that the simpletons are summoned to this identity by Tenniel's Lion-Tiger image, which is imprinted on the flag that the dashing soldier carries. Unlike the flag that the rurals carry (triangular and harking back to a pennon or lance flags that flourished in feudal and medieval times), the flag in the right frame is rectangular, denoting an elevated, if not actually national, status. The yokels become men and Britons by responding to the call of Britannia/British women in need of protection. It is noteworthy that women themselves are absent in "Willing Hands" except as a supine figure on the flag, the representation of a representation-a potent reminder that by this point real women had disappeared behind the icon. Tenniel's paired images of the immobile woman in need of aid and the tall, proud, heroic men rushing to protect her deftly encapsulate the deployment of 


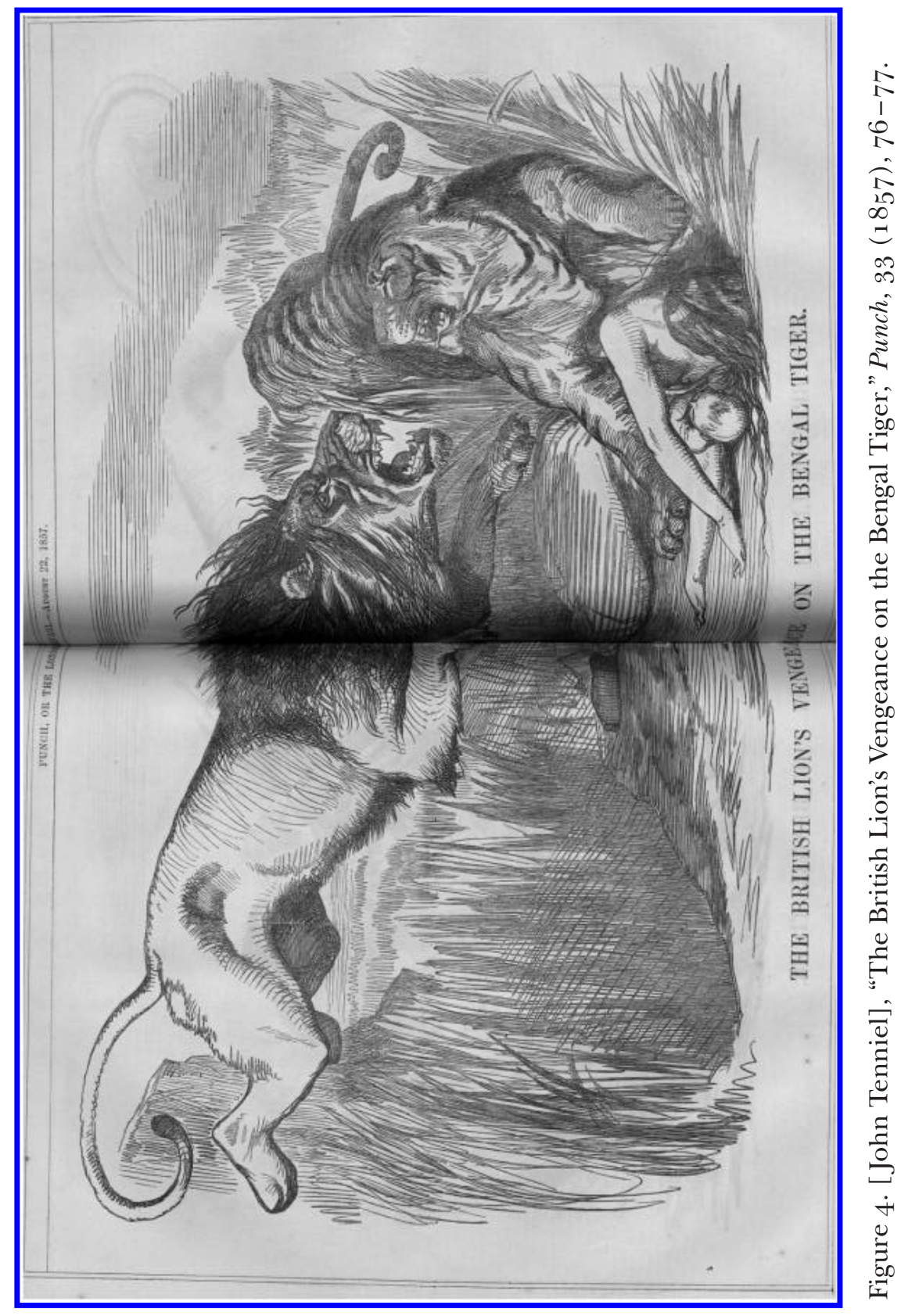




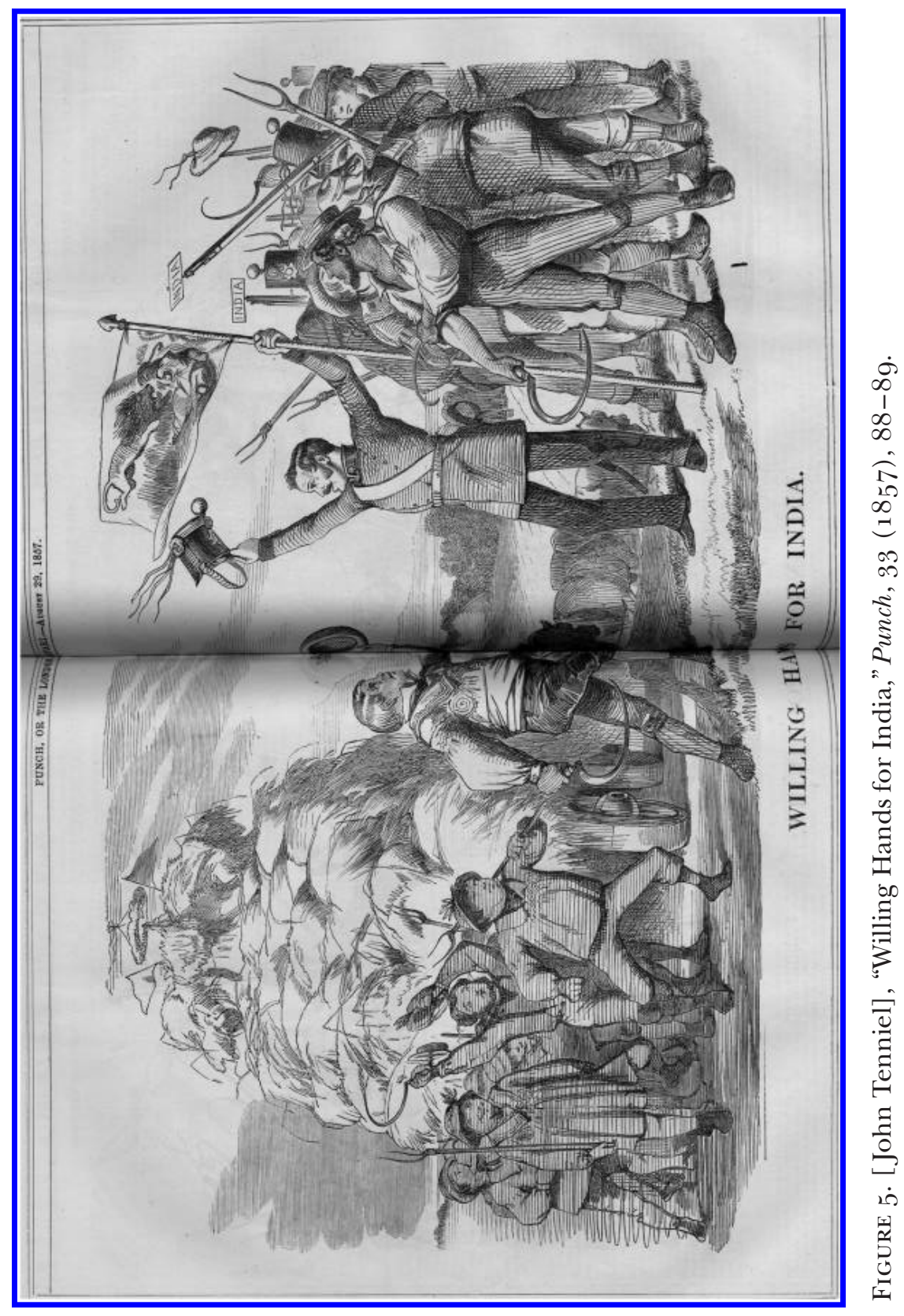


masculinity and femininity-each "properly" positioned-in the service of nationalism.

Why did the "Mutiny" evoke such responses? Why did it matter so? To address these questions I now, paradoxically, turn back in time to examine Dickens's pre1857 writings. I focus on his short fiction and journalism because, unlike his novels, these writings are concerned with the fate of Britons when they go abroad. In them Dickens repeatedly turns to themes of treachery and heroism, notions, as we have seen, central to Britons' scripting of the events in India. I conclude this section by arguing that the events of 1857 in India served to consolidate and focus Dickens's sometimes inchoate and dispersed sentiments into a celebration of British valor that laid to rest ghosts of disunity that had marred the national self-image and that Dickens had been repudiating in his fiction.

In 1788 Edmund Burke called for the impeachment of Warren Hastings, the first Governor General of Bengal. Burke charged Hastings with "avarice, rapacity, pride, insolence, ferocity, treachery, cruelty, malignity of temper, ... an inveterate blackness of heart, dyed in grain with malice, vitiated, corrupted, gangrened to the very core." ${ }^{27}$ Burke identified in Hasting's tenure "not only a long, connected, systematic series of misdemeanors, but an equally connected system of maxims and principles invented to justify them" ("Speech," pp. $265-66)$. Burke further charged:

An opinion has been insidiously circulated through this kingdom, and through foreign nations too, that, in order to cover our participation in guilt, and our common interest in the plunder of the East, we have invented a set of scholastic distinctions . . . by which we are to deny ourselves the knowledge of what the rest of the world knows. ("Speech," pp. 274-75)

\footnotetext{
${ }^{27}$ Edmund Burke, "From a Speech in Opening the Impeachment of Warren Hastings," in Edmund Burke: On Government, Politics and Society, ed. B. W. Hill (Fontana: Harvester Press, 1975), pp. 270-71.
} 
"Scholastic distinctions," "maxims invented to justify" misdemeanors: it was a bold move, as Burke was indicting not the man so much as Britain's form of colonialism. The effort failed, and, after a seven-year trial, Hastings was exonerated. In the following century, the "scholastic distinctions" or verbal acrobatics to stifle doubts about empire that Burke decried only increased. In 1855 , speaking to the Mechanics Institute, William Gladstone dismissed all of the customary reasons for holding colonies, such as wealth, status, territory, conquest, or trade. His rejections prepare one for a repudiation of colonialism, yet he concludes: "It is because we feel convinced that our constitution is a blessing to us, ... that we are desirous of extending its influence, and that it should not be confined within the narrow borders of this little island." 28 A piece of unabashed British exceptionalism, the lecture attests to the complacency that Burke had tried to disturb but that had instead grown pre-1 857 .

While Gladstone's speech expresses the self-confidence of 185 os Britain, Dickens's writings of the period are customarily read as less self-congratulatory. In a January $185^{1}$ lead article in Household Words, Dickens chastised the "State" for its ill treatment of its "children" and its "sacrifice of many valuable and dear lives." ${ }^{29}$ He urged Victoria: "Think of it, Great Queen, and become the Royal Mother of them all!" ("Last Words," p. 338). He called the soon-to-be-opened Great Exhibition a "worthy type of industry and ingenuity triumphant," but he went on dryly to propose an alternative Exhibition: "a great display of England's sins and negligences, to be, by steady contemplation of all eyes, and steady union of all hearts and hands, set right" ("Last Words," p. 338). Indeed, Dickens's novels of the early 185 os, beginning with Bleak House, attempt just that: to slice the

\footnotetext{
${ }^{28}$ Gladstone, "Our Colonies" (1855), rpt. in Imperialism and Orientalism: A Documentary Sourcebook, ed. Barbara Harlow and Mia Carter (Oxford: Basil Blackwell, 1999), p. 369. It would be inaccurate to suggest that there were no voices of restraint or dissent; the Radical Richard Cobden wrote of "crimes [in India] which would revolt any savage tribe," but his target was the East India Company, and he was writing privately (see Cobden, letter to Henry Ashworth, 16 October 1857, in John Morley, The Life of Richard Cobden, 2 vols. [New York: Macmillan Co., [1881], II, 206). Bryne charts working-class support for the rebels (see "British Opinion and the Indian Revolt," pp. 300-11).

${ }^{29}$ Charles Dickens, "The Last Words of the Old Year," Household Words, $4^{1}\left(18_{51}\right)$, 338,337 . Subsequent references are included in the text.
} 
top off "home" in order to "steadily contemplate" the Jos and Stephen Blackpools and Amy Dorrits of the nation, the "children" who were the human by-products of progress.

Yet to highlight only Dickens's distance from the mood of national self-aggrandizement is to tell a partial tale. His shorter writings in the years preceding the Indian Uprising sketch an alternative to the bureaucratically mired and socially unresponsive Britain of Bleak House, Hard Times, and Little Dorrit. Unlike the anchored and firmly located novels, Dickens's stories take place outside Britain, and the offshore settings allow him to imagine ideal situations. Largely maritime tales, these stories appeal to a spirit of adventure and also, in a period of railroad building and railway accidents, remind readers of Britain's supremacy on the seas. The tales are simple and rousing stories of ordinary men and women acting nobly, and they illuminate Dickens's thinking about Britishness in the years immediately preceding and following 1857 .

It is not coincidental that the stories I discuss below were written in the aftermath of and are shaped by the Franklin expedition, an event that left a searing impression on Dickens. In 1845 , to much fanfare and excitement, the elderly Sir John Franklin, who had fought with Horatio Nelson at Trafalgar and had published two earlier narratives of his arctic explorations, set off with a crew of 128 officers and sailors of the Royal Navy to search for the Northwest Passage. Last seen at Baffin Bay, they were never heard from again. Almost a decade later, in October 1854 , Dr. John Rae, leading a search party, concluded that all of the men had died of starvation and that some had turned to cannibalism in their final days. His account indicated that until the end the officers were evidently well fed while the sailors were bedraggled and starving, a detail that raised the specter of mutiny. Dickens was angered by the allegations and in December 1854 published a two-part rejoinder in Household Words entitled "The Lost Arctic Voyagers." ${ }^{30}$ Dickens denied Rae's allegations by questioning his sources and asserting the

\footnotetext{
${ }^{30}$ See [Charles Dickens], "The Lost Arctic Voyagers," Household Words, 10 (1854), $361-65$ and $385-93$. Subsequent references are included in the text. See also Rae's response: [John Rae], "The Lost Arctic Voyagers," Household Words, 10 (1854), 433-37; and "Dr. Rae's Report," Household Words, 10 (1854), 457-59.
} 
improbability of the account. Rae's conclusion that cannibalism occurred was based on the evidence of "Esquimaux" hunters. Dickens responded by discrediting "the vague babble of savages" and wondering if "Franklin's gallant band were not set upon and slain by the Esquimaux themselves," for "every savage [is] in his heart covetous, treacherous, and cruel" ("Lost Arctic Voyagers," pp. 365, 362). If we are inclined to overlook this sentiment as chauvinism merely spoken in the heat of the moment, Dickens's essay of the previous year "The Noble Savage" should give us pause. He begins the essay provocatively:

To come to the point at once, I beg to say that I have not the least belief in the Noble Savage. ... I don't care what he calls me. I call him a savage. . . he is a savage - cruel, false, thievish, murderous; addicted more or less to grease, entrails, and beastly customs; a wild animal with the questionable gift of boasting; a conceited, tiresome, bloodthirsty, monotonous humbug." 31

Ostensibly directed at those in Britain "whimpering over him [the savage] with maudlin admiration," the essay is a cringeinducing denunciation of "stamping, ramping, and raving" savages ("The Noble Savage," pp. 337, 338). ${ }^{32}$

In order to demonstrate the improbability of Rae's report, Dickens set out in "The Lost Arctic Voyagers" to prove that historically, under circumstances of dire adversity, "English seamen of the first class" never resorted to cannibalism ("Lost Arctic Voyagers," p. 363). He begins with Franklin's 1819-22 polar journey-an "enthralling" adventure of "heroic endurance" (p. 363) - and continues with a lengthy survey of the travel

${ }^{31}$ [Charles Dickens], “The Noble Savage," Household Words, 7 (1853), 337.

32 Dickens's essay echoes Thomas Carlyle's unnerving 1849 "Occasional Discourse on the Negro Question" (provocatively retitled "Occasional Discourse on the Nigger Question" in 1853) in which Carlyle excoriates "Exeter Hall Philanthropy" (see [Thomas Carlyle], "Occasional Discourse on the Negro Question," Fraser's Magazine, 40 [1849], 670-79). With more than his customary sarcasm, Carlyle writes: "But, thank Heaven, our interesting Black population,- - equalling almost in number of heads one of the Ridings of Yorkshire, and in worth (in quantity of intellect, faculty, docility, energy, and available human valour and value) perhaps one of the streets of Seven Dials,- are all doing remarkably well" ("Occasional Discourse," p. 671). The result of abolition and philanthropy, Carlyle writes, is that "while the sugar-crops rot round them uncut" and whites suffer, "Quashee" sits "up to the ears in pumpkins" (p. 671). 
literature of shipwrecks, concluding that it is "not the nature of the extremity; but, the nature of the men" that provokes what he euphemistically calls the "last resource" (p. 392). Dickens acknowledges two instances of cannibalism, one on an American ship where, after running out of food and water, the men shot a "negro" on board, "fried a part of him for supper, and pickled the rest" (p. 386). While the crew appear to have consumed the flesh, the captain, Dickens reports, refused. Of the other instance, Dickens writes: "we confidently assume the crew to have been of an inferior class" (p. 387). In other words, only Americans and those of the lowest classes would stoop to cannibalism. Franklin's "gallant band," Dickens reminds his readers, were "British naval officers," "noble," "brave," "manly," "enterprising," "highly disciplined," and "patient." Dickens concludes by demanding that the men's names be cleared of the "taint" because "they served their country well" (p. 392). In Dickens's logic, the men are upright because they are Britons, and, for elevating Britain's nobility-profile, the nation owed them gratitude. "The Lost Arctic Voyagers" is a straightforward Manichaean narrative, the first part debasing "savages," the second part elevating Englishmen for heroism and masculinity.

Shortly thereafter, in $185^{6}$, Dickens commissioned Wilkie Collins to write The Frozen Deep, the play that Dickens credited as his inspiration for A Tale of Two Cities. Although ostensibly Collins's work, the idea for the story was Dickens's and, as Lillian Nayder has demonstrated, the older man considerably revised Collins's early drafts. ${ }^{33}$ The plot involves two men's romantic rivalry over a woman, the men's dangerous expedition to the North Pole, and the spurned lover's heroic efforts to save his rival, even at the cost of his own life, for the women they both love. A fictional rendering of Dickens's arguments in "The Lost Arctic Voyagers," The Frozen Deep introduces the issues that Rae raised-class resentment, mutiny, cannibalism - and resolves them in the final unity of the rivals. The spurned lover, Wardour (played by Dickens in private performances), had earlier sworn to kill his rival when he discovered his identity,

\footnotetext{
${ }^{33}$ See Nayder, Unequal Partners: Charles Dickens, Wilkie Collins, and Victorian Authorship (Ithaca: Cornell Univ. Press, 2002), pp. 62-64.
} 
but, once abroad and "homeless," he changes his mind in order to secure the happiness of the woman he describes in terms that are practically synonymous with English femininity: "Young, with a fair sad face, with kind tender eyes, with a soft clear voice. Young and loving and merciful." ${ }_{34}$ The popular image of Victoria (as in the Punch cartoon in Figure 3) comes to mind. Having "made her happy," Wardour announces: "I may lay down my weary head now on the mother earth" and die (The Frozen Deep, p. 158). The image of a woman averts internecine strife, and "home" is saved. In Britain, a woman had stood between the men, but abroad, that same woman - now abstracted as "Woman" and symbolic of the nation-brings them together. In a foreign land, the very "domestic" that had been an obstacle to male bonding is, in heightened form, transformed into a grease that facilitates it.

As Collins was revising drafts of The Frozen Deep in $185^{6}$, Dickens worked on that year's Christmas number, "The Wreck of the Golden Mary." Also written collaboratively with Collins and several Household Words regulars, "The Wreck of the Golden Mary" is the story of an English ship on its way to California that sinks when it hits an iceberg. ${ }^{35}$ Thanks to the heroism of the captain and crew, everyone is rescued, but they spend a month in small boats on the sea before they are saved. The crew in this maritime tale are continually_and tediously —described as "constant," "restrained," "steady," "noble," "strong in adversity," "self-governing," "self-sacrificing," "forbearing," "orderly," "submissive," and "patient." These virtues are identified as quintessentially imperial and British; between them the captain and his first mate, John Steadiman, have

\footnotetext{
${ }^{34}$ Wilkie Collins, The Frozen Deep (1857), in Under the Management of Mr. Charles Dickens: His Production of "The Frozen Deep," ed. Robert Louis Brannan (Ithaca: Cornell Univ. Press, 1966), pp. $157,15^{6-57}$. Subsequent references are included in the text as The Frozen Deep.

${ }^{35}$ In quoting from the two Christmas stories that Dickens wrote collaboratively, "The Wreck of the Golden Mary" (1856) and "The Perils of Certain English Prisoners" (1857), I cite only from the portions written by Dickens. For an account of the authorship of the sections of each story, see Charles Dickens the Younger's "Notes," in Charles Dickens, Stories from the Christmas Numbers of "Household Words" and "All the Year Round," I $852-1867$ (London: Macmillan and Co, 1954), pp. xiv-xv; and Nayder, Unequal Partners.
} 
served in a variety of colonial outposts: the West Indies, China, Van Diemen's Land, and Saugar Point. ${ }^{36}$ Their voyages have strengthened their national and imperial identities: Steadiman once "struck [dead] a Malay and a Maltese" who were about to kill the captain of ship that is called, without irony, "Old England" ("Wreck of the Golden Mary," p. 85). Steadiman begins this voyage by decorating his cabin with "pictures . . . of the Blush Roses of England, the Blue Belles of Scotland, and the female Shamrock of Ireland" (p. 84). Britannia, literalized in the proverbial pinup that displays the variety and heterogeneity of the nation, travels with Steadiman to give meaning to an untutored seaman's journey.

The unyielding Arctic of The Frozen Deep is replaced in "The Wreck of the Golden Mary" by tossing seas, but the phantoms that haunt the tale are similar: mutiny and cannibalism. When first offered the position, Captain Ravender is informed that on missions to California "crews of vessels outward-bound desert as soon as they make the land; crews of vessels homeward-bound, ship at enormous wages, with the express intention of murdering the captain and seizing the gold freight" ("Wreck of the Golden Mary," p. 82). Though shipwrecked by an iceberg rather than mutiny, the danger of cannibalism arises as the survivors drift in the sea with dwindling supplies. Consequently, Ravender determines to "bring out into the light that unformed fear which must have been more or less darkly in every brain among [them]" (p. 97). To this end, he narrates the tale of Captain William Bligh's voyage following the mutiny on the Bounty, drawing out the moral that the "emaciated party" would "under no conceivable circumstances . . . have preyed on one another" ("Wreck of the Golden Mary," p. 97). "The Wreck of the Golden Mary" lays to rest the ghosts of mutiny and cannibalism that haunted the Franklin expedition and tainted British imperial masculinity, and it does so as "The Lost Arctic Voyagers" and The Frozen Deep did -in a foreign landscape, facing adversity, and protecting innocents, Dickens's men set aside their differences and become Britons.

\footnotetext{
${ }^{36}$ See Charles Dickens, "The Wreck of the Golden Mary," in Stories from the Christmas Numbers, pp. $8_{1}, 8_{3}, 8_{5}$. Subsequent references are included in the text.
} 
But "The Wreck of the Golden Mary" less successfully masks imperialism's other guilty secret: greed. When the captain is asked to undertake the "scheme," he hesitates until cajoled that it is "lucrative . . beyond doubt" ("Wreck of the Golden Mary," p. 82). Yet his, the crew's, and all of the passengers' acquisitive reasons for heading to California at the height of the Gold Rush are suppressed and displaced onto Mr. Rarx, a passenger whose "sordid" obsession with gold earns him everybody's hatred (p. 86). The desire for untold wealth that informs such voyages is of course the guilty underbelly of colonialism, a guilt that narratives such as Gladstone's worked assiduously to suppress. That such greed is displaced from the noble English sailor and the colonial venture he had been making possible for some two centuries onto the "hawk"-ish Mr. Rarx-who, although never named as such, is clearly supposed to be Jewish — only places Dickens in that Orientalist tradition of displacing guilt about one's darkest desires onto an Other. While Rarx openly covets gold, the crew and passengers worship "Golden Lucy," an angelic three-year-old girl whose blond tresses are a synecdoche for the gold they all seek, but whose innocence serves to launder that desire. The fair child is the embodiment of Britain, a point made explicitly by her attachment to Steadiman, who once protected "Old England" and who now protects her. Lucy dies, but the effort to save her "soften $[\mathrm{s}]$ " even men of "uncertain" and "rough temper," turning them "considerate" and "compassionate" ("Wreck of the Golden Mary," p. 95). The chivalry she evokes in the crew ennobles a voyage undertaken for greed and acquisition; indeed, it suppresses that greed and transforms it into nobility.

The following year, the news from India rekindled Dickens's savagery toward native peoples. In his infamous "extermination" letter of 4 October 1857 to Angela Burdett Coutts quoted earlier, Dickens fantasizes about being "Commander in Chief in India" so that he could "exterminate the Race upon whom the stain of the late cruelties rested; . . . to blot it out of mankind and raze it off the face of the Earth." The fantasy is at least as important as Dickens's extremism: it reveals a boyish fancy for leading the troops and a similarly childish desire for simplicity and clarity, for swift action to eradicate the undesir- 
able, for a world neatly divided into us-and-them, black-andwhite, right-and-wrong. Always contemporary and already thinking about fictionalizing events, Dickens wrote to Henry Morley, a colleague at Household Words, asking him to research whether an English colony existed, or could have, in South America. In his 18 October letter to Morley, Dickens explained that he "wish[ed] to avoid India itself" but wanted a setting "in which a few English people-gentlemen, ladies, and children - and a few English soldiers, would find themselves alone in a strange wild place and liable to hostile attack" (Letters, VIII, 469). The language - "strange wild place," "hostile attack"reveals Dickens's siege mentality, self-righteousness, and uncomplicated response to events in India.

The story that came of this research was the 1857 Christmas number, a tale "commemorating . . . some of the best qualities of the English character that have been shewn in India." 37 Written collaboratively with Collins, "The Perils of Certain English Prisoners" is set in a British colony off the coast of Honduras and tells of a pirate attack on the colony. The narrator, Gill Davis, is a private in the Royal Marines who, having served in imperial outposts of Jamaica and Belize, resents his superior officers as too "delicate." 38 Once he meets Miss Maryon, however, a young lady who describes herself as "an English soldier's daughter" and whom Davis predictably falls in love with, his mutinous class resentments melt and are replaced with national identification and pride ("Perils of Certain English Prisoners," p. 125). Miss Maryon is betrothed to someone else-a Jack Carton - and we are in the familiar territory of a heterosexual triangle that looks back to The Frozen Deep and forward to A Tale of Two Cities. It will come as no surprise to learn that one man, without a murmur, with considerable self-flagellation, and after he has come into his national identity, sacrifices his amorous ambitions for his rival. In this story, it is Private Davis who plays the Carton-figure, and he does so with a submission that is abject.

\footnotetext{
${ }^{37}$ Charles Dickens, letter to Angela Burdett Coutts, 25 November 1857 , in Letters, VIII, $482-83$.

${ }^{38}$ See Charles Dickens, "The Perils of Certain English Prisoners," in Stories from the Christmas Numbers, p. 125 . Subsequent references are included in the text.
} 
"The Perils of Certain English Prisoners" recycles and extends many of the themes of the previous stories. Like them, it is set outside Britain, this time in a colony on an uninhabited island. The setting realizes the colonial fantasy of an unpeopled land ready for the taking, and it permits Dickens to shed the aspect of colonies that was an encumbrance to the adventuring spirit: the mundane details of administering a people with different ideas. "Perils" foregrounds what was lurking but averted in The Frozen Deep and "The Wreck of the Golden Mary": mutiny. Yet, while in those stories the threat of mutiny came from fellow officers or sailors, here mutiny is realized, but its agent is a black man. The pirates succeed because the supposedly loyal "Sambo," Christian George King, turns out to be treacherous, "a double-dyed traitor, and a most infernal villain"-adjectives that echo the British characterization of the sepoys ("Perils of Certain English Prisoners," p. 138). The anxiety in the earlier stories about mutiny from within the ranks of the English is effectively dissipated here as mutiny is displaced onto the racial Other, freeing this tale's previously disgruntled private to rise to the occasion. Left to protect the women and children, Davis fights valiantly against King, whom he considers "no more a Christian, than he was a King, or a George" or, more provocatively, a "cannibal" ("Perils of Certain English Prisoners," pp. 124, 136). King is no doubt meant to evoke Fletcher Christian, the leader of the Bounty's mutiny, although the allusion to that debacle unwittingly reminds us what Dickens would rather suppress: that mutiny can come from "within," not just from native subjects.

Our brief exploration of Dickens's short fiction of the period indicates a pattern: the protagonist, often discontented or socially disruptive, while adventuring abroad falls in love with a woman who is the embodiment of English womanhood. Ennobled by this love to bury his differences and rivalries with his countrymen, he valiantly saves the lives of women and other innocents endangered by hostile foreign forces. It is a pareddown world that these stories long for and fictionally realize: for adventure and heroism in alien spaces, chivalric masculinity protecting femininity, and Woman-as concept rather than live entity-elevating men to sacrifice and glory. Dickens was 
by no means alone in expressing this desire for adventure and romance; one example from India will suffice. Mark Thornhill, a magistrate, had this to say of his flight to Agra in 1857: "[I] began to find something rather exhilarating in our position. It was such a pleasant change from our usual confinement indoors to be in the open air, and riding over the country at the head of a body of men seemed like acting in a part in a fairy tale. All possible adventures might be before us." ${ }^{39}$ The sense of boredom that Thornhill expresses offers one clue as to why many Britons, including Dickens, were seeking adventure, and indicates the central role that the "Mutiny" played in providing that adventure.

Rapidly scripted as a romance of knights and damsels requiring rescue, 1857 offered the literal landscape in which to enact the desire for heroism, adventure, and glory. In a perverse way, the "Mutiny" ignited or reactivated the spirit of adventure and escapade that, in the middle decades of the nineteenth century, was on the wane. In terms of national pride, there had been little to celebrate: the glories of Trafalgar and Waterloo were in the past; the excitements of acquiring a new empire with untold riches had been doused in cold water by efforts such as Burke's impeachment and Parliament's subsequent interventions; the adventure of opening new routes into Africa had died with Mungo Park; the moral glory of Abolition had been followed by the brutal suppression of slave uprisings in Demerara and elsewhere. Instead, particularly in the decade previous to the Rebellion, the vista was full of failures: the unsuccessful Niger Expedition of 1841, the horrifying rumors about the Franklin Expedition of 1845 , the ignominious Crimean War of $1854-56$.

Yes, there was the glory of the Great Exhibition, but the very domestication of adventure, danger, and exploration that it literally enclosed is precisely the loss I am identifying. Debo-

${ }^{39}$ Mark Thornhill, as quoted in Gautam Chakravarty, The Indian Mutiny and the British Imagination (Cambridge: Cambridge Univ. Press, 2005), p. 129; emphases added. The original source is Thornhill's The Personal Adventures and Experiences of a Magistrate during the Rise, Progress, and Suppression of the Indian Mutiny (London: John Murray, 1884), p. 48 . 
rah Wynne, in a subtle reading of the first article on the Crystal Palace to appear in Household Words, written by Dickens's subeditor, W. H. Wills, demonstrates this point. ${ }^{40}$ Wills's "The Private History of the Palace of Glass" $\left(18_{5} 1\right)$ begins with an adventuresome botanist in Demerara. The setting and themes are familiar: unexplored territory, an intrepid explorer, tremendous danger and odds, a serendipitous find (a "Titanic" water lily), and the reward-samples brought to Britain, where the flower is renamed "Victoria Regia" and coaxed by Paxton to multiply in the nontropical climate of London. Wynne notes:

The article's initial excitement about a dangerous journey into unexplored territories and the appropriation of native treasures gives way to a different excitement centred on the more recent "adventures" of engineers and inventors, forging new products and designs for the marketplace. The romance of imperialist expansion in the 183 os is replaced with.... [the search] for cheap raw materials and the most cost-effective means of production as the route to national glory. ("Responses to the $185^{1}$ Exhibition," p. 230)

Exploration and expansion is brought home and domesticated into pounds and shillings. While Wills may have found the "adventures" of engineering exciting, Dickens did not, complaining to Wills about the "dustyness" of the journal's essays (consequently, as Wynne points out, halfway through the year more irreverent articles about the Crystal Palace started to appear in the pages of Household Words) ${ }^{41}$ The shift from imperial adventure to the pursuit of the "arithmetical skill" that so captivated Wills is precisely the domestication I am charting. ${ }^{42}$ No matter how celebratory or self-satisfied a Briton may have felt about the Great Exhibition (and Dickens felt neither), it was, in fact,

\footnotetext{
${ }^{40}$ See Deborah Wynne, "Responses to the $185^{1}$ Exhibition in Household Words," The Dickensian, 97 (2001), 228-34.

${ }^{41}$ See Wynne, "Responses to the $185^{1}$ Exhibition," pp. 231-32. For Dickens's complaint to Wills, see Charles Dickens, letter to W. H. Wills, 16 October $185^{1}$, in Letters, VI, 522 .

${ }^{42}$ See [W. H. Wills], "The Private History of the Palace of Glass," Household Words, 2 $\left(185^{1}\right), 388$.
} 
a long way from intrepid travelers and adventure in foreign lands. Despite the public excitement it generated, the Exhibition was all too often mired in workaday details, the sort that masked the "intrepid" nature of the enterprise. ${ }^{43}$

No place better epitomized the decline from swashbuckling adventurism to administrative tedium than India in the first half of the nineteenth century. Gone were the days of spectacular conquest, untold riches, and romance, of Robert Clive, Richard Wellesley, and nabobs. Such exploits and adventures were replaced by events like the disastrous First Anglo-Afghan war of $1838-42$, led by the lackluster Lord Auckland. As Parliament became increasingly involved in supervising the East India Company's activities, India came into British public consciousness, but primarily as a battleground for competing ideologies between, for example, Evangelicals and India hands, Orientalists (Sir William Jones) and Anglicists (Macaulay). In the decades before 1857 , the administration of India was mired in endless debates about land assessment and tax collection, the virtues of one educational policy over another, the titular rights of native princes and heirs and the legal basis of annexation, the competing claims of missionaries and local religious leaders. In short, for most Britons India stood for the dead weight of administrative minutiae. In this morass the "Mutiny" occurred, allowing Britons to relive the glory days of adventure, heroism, and romance. The Indian Uprising stirred the blood and raised the spirit, it united Britons and restored "proper" gender relations, it offered clarity without having to go through the cartwheels of an argument such as Gladstone's, and it subdued the colonial guilt that Burke had so tenaciously sought to give a name. Writing in 1857 in British Rule in India, Harriet Martineau commented that India was not "considered worth study by the British at home till calamity ... [made] every nook and corner of it as fearfully interesting to the people at large as the interior of Africa to the Parks of Peebles, and the Polar re-

${ }^{43}$ This notion is underscored in James Buzard, "Conflicting Cartographies: Globalism, Nationalism, and the Crystal Palace Floor Plan," in Victorian Prism: Refractions of the Crystal Palace, ed. James Buzard, Joseph W. Childers, and Eileen Gillooly (Charlottesville: Univ. of Virginia Press, forthcoming 2007). I am grateful to the author for sharing the essay pre-publication. 
gions to the Franklins and Kanes." ${ }^{44}$ Martineau's allusions to the explorations and imperial adventures that cemented national identity underscore my argument that the Uprising arrived at a propitious moment to rouse British men's and women's identities as Britons once again as they were flagging.

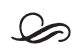

We are now ready to return to the questions that I posed at the start of this essay: why did Dickens write about the French Revolution in 1859? Where is the Indian "Mutiny" in A Tale of Two Cities, and what, if any, role did it play in this novel that stands in such contrast to Dickens's other novels of the $185 \mathrm{os}$ ? There are certainly references to the events of 1857 in A Tale of Two Cities. Earlier I mentioned the mutinous figures in the novel, but other, more unsettling echoes of the Uprising emerge. For instance, Gaspard, who kills the Marquis to avenge his son's death, is himself killed and hung over the village fountain, poisoning the water and leading the mender of roads to complain: "How can the women and the children draw water!" (Tale of Two Cities, p. 207). The allusion to the well at Kanpur is unmistakable. Madame Defarge, with a "bright shawl" wrapped around her head like a turban and large, gypsy earrings (pp. 37-38), is Orientalized from the start, but becomes Indianized first when her "shadow" falls, "threatening and dark, on both the mother and the child" (p. 328), and then when she becomes a "tigress" with the single-minded obsession to destroy Lucie and her daughter (p. 447). Both descriptions evoke Tenniel's Tiger menacing the helpless woman and child.

But what might such references suggest? That for Dickens the Indian rebels are analogous to the French underclass? That the East India Company, like the French elite, reaped what it sowed? That Dickens had a "secret sympathy" for Indian rebels? That Darnay and Lucie represent the English in India, and Madame Defarge represents the Indian rebels? Any effort at developing such analogies proves unsatisfactory and difficult to

44 [Harriet Martineau], British Rule in India: A Historical Sketch (London: Smith, Elder, and Co, 1857), p. 13 . 
sustain. Grace Moore, in Dickens and Empire, for instance, maps the infamous story of General Wheeler's daughter in Kanpur, who is reputed to have fought off her abductor, onto Miss Pross and concludes that Miss Pross "takes on board a number of identities and becomes a representative of Anglo-Indian womanhood in its entirety" (Dickens and Empire, p. 154). The reading feels forced, especially as, in this and other instances, Moore provides no explanation for why Dickens would substitute France for India. Moreover, the analogies that she develops are frustratingly inconsistent: in one moment Miss Pross stands for Anglo-Indian women, suggesting Dickens's sympathy for the English in India, and in another the Monsignor signifies the Company and indicates Dickens's sympathy with Indians (Dickens and Empire, p. 130). Ultimately, Moore's contention that A Tale "allegoriz[es]" the "Mutiny" feels unconvincing and unilluminating (Dickens and Empire, p. 141).

In his 25 November 1857 letter to Angela Burdett Coutts, Dickens wrote that in "The Perils of Certain English Prisoners" he wanted to create a story that made no "vulgar catchpenny connexion or application" to India (Letters, VIII, 482). I wish to borrow this approach in my analysis of A Tale of Two Cities. Rather than looking for parallels or analogies between 1857 and Dickens's account of the French Revolution, I come to the novel from the directions I have sketched: through the cultural anxieties of the $185^{\circ}$ os, especially the desire for national glory and triumph; through the search, during a period of prosperity and domesticity, for adventure; and to the place of a buccaneering form of imperial assertion in the articulation of national identity. While I trust it is evident by now, let me clarify what I am not arguing: I am not suggesting that A Tale of Two Cities is "about" the Indian "Mutiny." Rather, I am arguing that the events of 1857 animate the novel. If we consider the response to the events of 1857 as part of a wider longing for nobility that ignited national self-articulation in Britain, and if we read the novel against this backdrop, then A Tale of Two Cities reads less as a "French Revolution novel" than as one about the "Making of Britons."

"If it was ever intended," thunders Miss Pross to a startled Jarvis Lorry, "that I should go across salt water, do you suppose 
Providence would have cast my lot in an island?" (Tale of Two Cities, p. 31). Lorry is felled by the question, but we need hardly be. Of course, it was intended, if not by Providence then at least by Dickens, that she should cross salt water, because only in making the Dover-Calais crossing-which she does without murmur seventeen years later-can Miss Pross be transformed from a "wild-looking," mannish red-head into first an "Englishwoman" and then, more definitively, a "Briton" (Tale of Two Cities, pp. 30, 453, 454). What does it mean to be a Briton? In the logic of this novel, one is not born a Briton but becomes one. And to become a Briton requires that one make The Crossing and A Sacrifice (or more precisely, self-sacrifice). In making The Crossing, Miss Pross finds the enemy through whom she can transcend her role as a bully of servants and of Mr. Lorry to become a genuine Briton. In her death struggle with Madame Defarge, Miss Pross's earlier comical jingoismher insistence on cooking food that is at least "half English" ( $p$. 117 ), her refusal to learn French and mockery of French ideals (pp. 357-58), her shopping in Paris in an absurd sign language and getting bargains nevertheless (p. 357) - is transformed into nobility and self-sacrificing valor. "I don't care an English Twopence for myself," she shouts at Madame Defarge (p. 454), in what could well be the novel's primer for "How to Become a Briton." Articulating her self-sacrifice in the idiom of monetary sacrifice, Miss Pross, like Wardour in The Frozen Deep, Steadiman in "The Wreck of the Golden Mary," and Davis in "The Perils of Certain English Prisoners," acts heroically without seeking reward, thus reaping a far greater treasure: the right to call herself a Briton. Whereas earlier she had described herself as "a subject of His Most Gracious Majesty King George the Third" (Tale of Two Cities, p. 358; emphasis added), in her struggle to protect her "Ladybird," Miss Pross is transformed into an agent who has earned the right to claim "I am a Briton" (p. 454). Her deafness is her battle scar, the bodily wound that she carries to mark her becoming. (From our perspective, it is also an apt if unwitting metaphor for Victorian jingoism's inability to hear any logic but that of its own certainty.)

Jerry Cruncher too is transformed in The Crossing from a wife-beating, class-resenting grave robber to an upright man 
who, with only the slightest prod of disapproval from Mr. Lorry, sacrifices his lucrative sideline of retrieving bodies and accepts that his proper place in the order of things is to receive them. The best Briton, of course, is Sydney Carton. Initially stereotypically "French" in his dissipation and enervation, his lack of ambition and sneering disdain, Carton becomes a Briton in France when he recognizes that, rather than sacrifice his talents to Stryver's professional ambitions, he should sacrifice his life for Darnay's domestic ones. When he conceives his plan to exchange places with Darnay, Carton takes a number of symbolic steps: he stops drinking, pouring away the brandy that Lorry offers him; decides that "these people [the Defarges] should know there is such a man as [he] here"; "alter[s] the disordered arrangement of his loose cravat, and his coat-collar, and his wild hair"; and, despite his fluency in the language, speaks to the Defarges "in very indifferent French" (Tale of Two Cities, pp. 417-18). Having shed everything "French"-drink, effeminacy, wildness, language - he can triumphantly declare to Madame Defarge: "Yes, madame, yes. I am English!” (p. 418). As in Dickens's short fiction, here too national identity is awakened via Sacrifice in a hostile, foreign land and through an investment in domesticity - a domesticity that, presided over by the gentle, goldentressed Lucie, insistently announces itself as Britain. ${ }^{45}$ Such feminized and domestically inflected nationalism smoothed the rough edges of-indeed suppressed-an aggressive imperialism and masculinity that were visible in gold-seeking colonial adventures, in the Highland oath, and in Tenniel's images.

And yet the carriage that leaves France to return to London at the end of the novel has no room for these three exemplary Britons-Miss Pross, Jerry Cruncher, and Sydney Carton. Neither Dr. Manette nor Lucie nor Darnay is British by birth or can claim British nationality. Nevertheless, for the novel they

\footnotetext{
${ }^{45}$ When Mr. Lorry first meets Lucie, her fairness and blue eyes cause her to stand out in a room darkened by imperial ventures: Lorry crosses a "Turkey carpet" to reach her where she is practically swallowed up by a "gaunt pier-glass behind her, on the frame of which, a hospital procession of negro cupids, several headless and all cripples, were offering black baskets of Dead Sea fruit to black divinities of the feminine gender" (Tale of Two Cities, pp. 22-23). Lucie brings into this "large, dark room," where even candlelight appears to be buried in the "black mahogany," the proverbial light of progress and enlightenment.
} 
are Britons; further, they are the Britons most worthy of rescue. Darnay, whose birth is an inheritance he cannot shake in France despite his intentions and good actions-"At heart and by descent an Aristocrat," the final jury voted (Tale of Two Cities, p. 411) - can in London transcend this same birth and become British. He does this by Sacrifice-in this case giving up his property and "labor[ing]" with "great perseverance and untiring industry" (p. 155). One could demur that his sacrifice pales in comparison to Carton's life and Miss Pross's deafness, but such a feeble sacrifice seems fitting for a rather spectral character. Lucie's status as Briton is more interestingly managed. In Paris she is declared a "citizeness of France" (p. 349), but in Dickens's eyes she is wholly British. This is so not because her mother was English or because she has lived in Britain since she was two-recall that she speaks with "a little foreign in [her] accent" (Tale of Two Cities, p. 23) - but rather because of her untiring sacrifice in recalling her ghostly father to life, a plot that absorbs much of the narrative. When Dr. Manette sacrifices his health and jeopardizes his life to save his son-inlaw, a man he had denounced in a previous life, Lucie is his model. Through The Crossing (multiple ones, in their cases) and Sacrifice, these French citizens become not only Britons, but also the novel's most valuable ones.

Such a borderless version of British nationality, the evident openness and pluralism about who is or can become a Briton, seems laudatory, particularly in light of the old Anglo-Gallic rivalry that was always quick to flare. Linda Colley has argued that British national identity was cemented in the eighteenth century not by flattening differences between the English, Welsh, and Scots, but by the growing belief that the British were different from those beyond their shores, especially the French. ${ }^{46}$ Gathering in and embracing Darnay, Lucie, and Dr. Manette as flawless Britons, A Tale of Two Cities signals a shift: rather than regurgitate the old Anglo-French antipathy, it goes a considerable way toward smoothing over that antagonism. Indeed, Dickens even goes so far as to suggest that the British and

\footnotetext{
${ }^{46}$ See Colley, Britons: Forging the Nation, $1707-1837$ (New Haven: Yale Univ. Press, 1992), pp. 5-7.
} 
French, albeit to different degrees, share a reverence for noble action. Thus, even Madame Defarge, the character who lies utterly outside the novel's range of sympathies, is not entirely without nobility or heroism. Described as "of a strong and fearless character, of shrewd sense and readiness, of great determination ... [and] beauty," she boasts all the raw materials of heroism (Tale of Two Cities, p. 447). Unfortunately, in her they have been perverted by "a brooding sense of wrong" (p. 447). Although the novel cannot approve of her actions, its latebreaking revelation that she is the sister of the peasant girl raped by the aristocratic Evrémonde provides her vengeance with a motive. Motive, of course, is what "cowardly" Indians of the post-1857 iconography lack. That even Madame Defarge has the kernel of nobility suggests a realignment of historical antagonisms - some French could be naturalized, while others were offered at least the dignity of motivation.

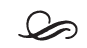

Where is the Indian "Mutiny" in A Tale of Two Cities? As I have indicated, aside from a few allusions- to poisoned village water and mutinous behavior-the "Mutiny" itself does not make a serious appearance in the novel. Its absence, however, suggests neither that Dickens had managed the rage he expressed when he first learned of 1857 nor that he had reversed his views nor that he expressed his views in a thinly veiled allegory nor yet that the events of 1857 had left no mark on his thinking. On the contrary, I have tried to suggest that something more subtle was at work- that the Indian "Mutiny" focused and strengthened Dickens's yearning for a unified British identity and his conviction that such an identity is forged in a foreign landscape. For Dickens differences that are divisive at home can be overcome in the cause of protecting the "domestic" - in both micro and macro senses of the word. It is ironic that it was the very domesticity of mid-nineteenth-century British culture that fueled Dickens's and others' desire for escape and adventure. Having escaped "home," it could now be safely abstracted and elevated into its macro sense of "nation." 
Why did Dickens write about the French Revolution instead of the Indian "Mutiny"? Any answers to this question can only be speculative. Dickens's comments to Morley and Burdett Coutts suggest that he wished not to be read topically. Moreover, writing about 1789 provided a way to manage the anxiety, sense of catastrophe, and lack of control that Britons felt as news of the Rebellion sunk in. Recalling an event that was as horrifying as India but that, from the distance of historical perspective, had turned out all right, Dickens could offer some detachment. Already in "The Wreck of the Golden Mary" and "The Perils of Certain English Prisoners" we see the desire for detachment from the everyday and the bureaucratic accomplished by turning to the fantasy-adventure genre. A Tale of Two Cities, written in a time of greater trauma, offers distance by turning to historical fiction.

I want to end by looking at two moments in A Tale of Two Cities in which Dickens utilizes the convention that the genre allows and the narrator steps out to speak in a detached or prophetic voice. These moments attempt to reduce the terror of the moment by absorbing the present into a "cycles-of-time" perspective that palliates by offering a wide-angled perspective. The final paragraph of the chapter entitled "The Grindstone," as if exhausted by the effort of capturing the frenzy it details, begins thus: "The great grindstone, Earth, had turned when Mr. Lorry looked out again, and the sun was red on the courtyard" (Tale of Two Cities, p. 323). This evocation of a spinning earth takes the most detached view possible: the "lesser grindstone," the one used by the mob to sharpen knives, will be absorbed or muted by the greater grindstone, Earth. If "Nature red in tooth and claw" was Tennyson's despairing account of Nature's unconcern for mankind, then that same detachment or disinterest offered Dickens comfort because it diminished human actions-desirable when faced with the horror of the Terror or the "Mutiny."

Dickens was seeking, however, not just comfort but control. In the novel's opening chapter, amid references to current events such as Mrs. Southcott, the Cock-lane ghost, and burglaries, the narrator steps in and changes direction: 
It is likely enough that, rooted in the woods of France and Norway, there were growing trees . . . already marked by the Woodman, Fate, to come down and be sawn into boards, to make a certain movable framework with a sack and a knife in it, terrible in history. It is likely enough that in the rough outhouses of some tillers of the heavy lands adjacent to Paris, there were sheltered from the weather that very day, rude carts, bespattered with rustic mire, snuffed about by pigs, and roosted in by poultry, which the Farmer, Death, had already set apart to be his tumbrils of the Revolution. (Tale of Two Cities, pp. 2-3)

Woodman Fate's and Farmer Death's obliviousness is chilling, but the narrator's ability to "predict" their actions, to trace an innocuous act to its horrifying conclusion is, paradoxically, comforting. As the unthinkable happens - the "Mutiny," the failed Franklin Expedition-Dickens's desire to order and control his world is realized, at least partially, in the form of the historical novel. The promise that Dickens holds out in A Tale of Two Cities to a reader seeking comfort is the refuge that Britain and British national identity provided in 1789 - a tale of stability and coming together to preserve "home." If something as terrifying as the French Revolution created better Britons, Dickens promises his readers, then so would 1857 . It was, to paraphrase Martin Green, a comforting bedtime story. ${ }^{47}$

\section{University of Puget Sound}

\section{ABSTRACT}

Priti Joshi, "Mutiny Echoes: India, Britons, and Charles Dickens's $A$ Tale of Two Cities" (pp. 48-87)

This essay asks what, if any, import the Indian "Mutiny" of 1857 had on A Tale of Two Cities (1859), Charles Dickens's fictionalized account of the French Revolution. Begun shortly after the Indian uprising started, Dickens's historical novel appears studiously to avoid any mention of events on the Indian subcontinent, even though these events preoccupied and enraged the author. Few scholars have attended to the question of $A$ Tale of Two Cities and the "Mutiny," but when they have, scholars have looked for analogies between India and Dickens's account of the French Revolution. In this essay, by contrast, I examine A Tale of Two Cities in a larger context-of Britons' response to the Uprising, of Dickens's short stories and essays in Household Words in the years before the "Mutiny" and immediately after, of Dickens's disenchantment with aspects of British

\footnotetext{
${ }^{47}$ See Green, Dreams of Adventure, Deeds of Empire (New York: Basic Books, 1979), p. 3.
} 
culture, and of his need to articulate a national identity grounded in action. I argue that the events in India were the match that ignited Dickens's already established midcentury interests in national identity, nobility, and masculine heroism. I do not wish to suggest that A Tale of Two Cities is an Indian "Mutiny" novel, but rather that it is a novel about the "Making of Britons," an important endeavor for an author who was intensely dissatisfied with the Britain that he saw around him.

Keywords: Charles Dickens; A Tale of Two Cities; Indian "Mutiny" of 1857; Household Words; illustrations from Punch 